\title{
Towards A Sustainable Ethical Paradigm for Postmodernity: M.K. Gandhi and Emmanuel Levinas
}

\author{
T J Abraham \\ Associate Professor, Dept. of English, St. Thomas College Pala.
}

\begin{abstract}
Absract: The alleged impossibility of ethics after poststructuralism has been of some concern for everyone as ethics directly bears on the sustainability of the universe. The thought of M.K. Gandhi and Emmanuel Levinas, two visionaries of the East and the West, is selected as touchstones, to demonstrate both the viability of ethics as well as the inclusive character of their views. Even as one can hardly call Gandhi as a poststructuralist, Gandhian ethical framework is attuned to post structuralism. The thought of Levinas bears the stamp of approval of Derrrida himself.
\end{abstract}

Key words: ethics, poststructuralism, Gandhian thought, Levinas, sustainability, postmodernism

\section{Introduction}

Ethics, at once an inquiry into, and the basis of, the principles that shape one's perception and govern one's conduct, though of perennial interest, has gained unprecedented urgency in the wake of the rather palpably nihilistic undercurrents of the poststructuralist thought. ${ }^{1}$ To say that the antiessentialist and antifoundationalist position of poststructuralism, swears by absence or negation, is a common place. And this necessitates one to explore, both the viability of a thought system based on negation and absence, as well as the status of an ethics underpinned by such a system. ${ }^{2}$ And, this paper tries to enquire into both the alleged impossibility of ethics after poststructuralism as well as the way the conceptual frameworks offered by M.K. Gandhi and Emmanuel Levinas circumvent the issue regarding the unworkability of Ethics, assuming optimum sustainability to be the ultimate test of truth of the universe.

Gandhi and Levinas, as representatives of the two broad global thought systems and as individual thinkers, in their varied yet surprisingly parallel routes, accord the pride of place to Ethics. When Jacques Derrida famously declared that "the repercussions of his [Levinas's] thought will have changed the course of philosophical reflection in our time" $(1999,14)$, it was more a tribute to the ability of the Levinasian thought system to redeem poststructuralism ${ }^{3}$ from the disastrous course of nihilism it was then taking than its agreeability to gel with Derrida's own deconstructive enterprise. Even as any stretch of imaginative enterprise would be hardpressed to read Gandhi as a poststructuralist thinker, one can, as demonstrated in the following section, with considerable cogency, make a case for Gandhian ethics as most germane to postmodernity.

\section{Gandhi, Levinas And Modernity}

Significantly, both Gandhi and Levinas direct their critique towards modernity, to surprisingly similar effect. Yet, far from a return to premodernity, which would be incorrigibly retrograde, the two thinkers, in their characteristically different ways, champion a new model to negotiate postmodernity in a sustainable framework. Gandhi and Levinas together share a field that addresses the failure of modernity. Even as the unprecedented achievements of science and technology, liberal political organization, and socioeconomic improvement engendered a sense of confidence of a world mastered by humanity, modernity set foot in trailing far too many issues like pollution, ecological disaster, Holocaust and so on, most of which appeared insoluble. Gandhi ${ }^{4}$ and Levinas emerge in history as seers, who, foreseeing the inadequacy and failure of the grand narrative of progress rather mistakenly shared by people at large including the Third World, advocated a sustainable model of development. And if postmodernity is marked by the end of the Enlightenment dream of mastery over nature and a revelation of the insufficiency of rationality and science, Gandhian thought, for sure, anticipated the shape of things in store. If Gandhi entered politics, it was not to liberate his country in the sense generally understood in the West, "but to establish the Kingdom of Heaven or Ramarajya" (Tidrick xi) which again, far from a transcendental realm, is a veritable heaven on earth for Gandhi.

If Gandhi was prophetic in his assessment of modernity, Levinas, rather late in chronology, was addressing a world that was becoming disillusioned with "the growing awareness that the 'modern' is something to which we are condemned" (Sim 320). If Gandhi's prognosis was exact, Levinas's remedy was as discerning as his diagnosis was insightful. While Levinas's ethics is turned towards fractured human self that calls for help, Gandhian thought has its origin in the context of domination and oppression on the basis of social (caste), political (colonial and racial), and economic (class) organization. So much so, both Gandhi and Levinas may be 
said to take off from a common basis - "the conviction that morality is the basis of things and that truth is the substance of all morality" (Gandhi 1927, 29).

\section{Gandhian Ethics And Poststructuralism}

Truth and Nonviolence (Satya and Ahimsa) central to Gandhian thought, may be ewed largely as a programme to offset the evil of modernity that was predicated on Enlightenment project that culminated in industrialism, colonialism and nationalism, all of which symbolized, for Gandhi, hardcore violence under cover. And violence being evil, had to be resisted.

The relevance of Gandhism may be primarily its sustainability as a 'philosophy'. While such celebrated theoretical systems like poststructuralism, need to live or die with a set of inherent contradictions, Gandhian programme is less riven by such insoluble antinomies. Yet Gandhi may be viewed as a postmodernist in terms of the crucial postulates on which his thought is predicated. Viewed from their ultimate projects, Gandhism and postmodernism share a common platform. If postmodernism can be viewed fundamentally as a project of liberation and restoration of the marginalized, in terms of gender (women), class (working class), race (postcolonial) and the nonhuman (ecological), to their rightful place, Gandhian thought seeks to do it par excellence. Yet there are some fundamental differences between the two as well. However, if differences are evaluated in terms of their sustainability, Gandhian thought in spite of its outmoded feel, as the paper is going to argue, emerges as a viable alternative to poststructuralism. For, as Tidrick puts it, Gandhian "ideas, though clothed in Hindu terminology, were not Hindu in origin" (xi).

One might say that Gandhi's critique of modernity more as an antidote to, than as an acceptance of, the sense of fragmentation and meaninglessness, parallels in many ways the postmodernist vision. Gandhi, with surprising perspicacity, foresaw, as it were, the postmodern stage strewn with a heap of dead bodies, consequent on the systemic violence - death of man (Foucault), death of God (Nietzsche) death of the author (Barthes), death or end of history (Fukuyama), death of philosophy (Heidegger) and so on. Gandhian Ahimsa, so to speak, counters it by muffling the reverberations of the celebratory guffaw on the postmodern stage. Indeed, Gandhian conceptual framework of truth and nonviolence holds out a more sustainable prospect for a self conscious modern subject hemmed in by agency and pure absences.

That modernity in the East and the West had different manifestations is a cliche. The Western experience of it as science and technology, capitalism and industrial enterprise, liberal democracy, nation states and World Wars, and the Eastern one in the shape of imperialism, colonialism and racism overreached by derivative ideas filtered through the academies, were both unwholesome. Interestingly, Gandhian thought, primarily a response to the Eastern manifestations of modernity is at once an answer to the Western variety and the perennial issues concerning humanity.

Gandhi viewed Western modernity as violent, and hence, resorting to violent decolonization, ${ }^{5}$ for him, was to be adopting the worst features of Western civilization. That the Western model was flawed was clear to him: "To arm India on a large scale is to Europeanize it. Then her condition will be as pitiable as that of Europe ... Those who are intoxicated by wretched modern civilization think these things" (Parel 77). The pitfall of imitating the Western model has come in for fierce resistance from Third World intellectuals, among whom Frantz Fanon whose model is contradistinguished by the advocacy of violent decolonization underscores the need for a new model fashioned by native peasantry. Yet, rather surprisingly, the Gandhian model of decolonization and development hardly find a place in the mainstream postcolonial canon. It may be no less because the mainstream Western academy is yet unconvinced about the significance of Gandhian scheme of decolonization, than their inability to valorize a thought system based on anything other than competition.

Methodologically, both Gandhi and Levinas take off from the rather seemingly negativist 'nonviolence' and 'Thou shalt not kill', respectively. Both are diehard humanists, as Gandhi emphatically declares: "individual is the one supreme consideration" (YI November 1924), and Levinas, dismissive of the antihumanist fad of contemporary Western academies, rejects classical humanism, paradoxically, for being not sufficiently humanist: "Humanism has to be denounced only because it is not sufficiently human" $(1991,128)$. Yet, for Gandhi, humanism is far from individualism, and he emphasizes, that "Unrestricted individualism is the law of the beast of the jungle" (H May 1939). Instead, Gandhian humanism aims to uphold the dignity of an individual, by a "Willing submission to social restraint for the sake of the well being of the whole society" ( $\mathrm{H}$ May 1939). Notably, Gandhian humanism, as indeed his other concerns, is subservient to ethics, as he says: "the end to be sought is human happiness ... I use the adjective moral as synonymous with spiritual" (H January 1942).

It may be informative to note how the Gandhian thought is able to achieve, with the least contradiction, the same end as postmodernism as far as the marginalized are concerned. When Gandhi identified God with Truth, and both of which with the substratum of the universe, he, far from being foundationalist, was rejecting the Judeo-Christian God, in favour of Truth to which one may endlessly strive: "My uniform experience has convinced me that there is no other God than Truth. And . . . the only means for the realization of Truth 
is ahimsa" $(1927,419)$. Besides, by the identification of love of humanity with love of God, it seeks to steer clear of the charge of being trapped in a metaphysics of presence.

In the same vein, Gandhi's famous observation to an atheist, that the "fellow feeling which makes you feel miserable, because of your brother's misery is godliness, ... so long as you feel akin with mankind you accept God in practice" (quoted in Iyer, 124), stresses the ultimacy of human welfare. And as he goes on to consider, "the voice of God, of conscience, of Truth as the same thing" (H July 1933), though it ostensibly clashes with certain postulates of poststructuralism, it will pass off as a better option in terms of sustainability.

Apart from the common starting point of noninjury for both Gandhi and Levinas, both view ethics as preceding everything. Iyer observes that "Gandhi held that the Moral Law is logically prior to the existence of God, that the obligatoriness of the law does not derive from God's willing his creatures to obey it" (155-56). And such a view, tantalizingly close to the Kantian wonder about the starry sky above and the moral law within, yet again tries to surmount the problem of presence. However, while Levinas's ethics springs from the fractured radical alterity, for Gandhi, it is the unified mind or conscience: "There is an almost centre of us all, where Truth abides in fullness" (YI July, 1931).

The Gandhian ethics, contrary to the popular perception about the Eastern thought in general as worldnegating, sets great store by life on earth. Moksha, traditionally held as the highest end of life is secondary for Gandhi. Even Dharma, often regarded as the supreme value, "has no meaning apart from Lokasamgraha, the welfare of the whole world" (Iyer 67). Besides, Moksha, being no transcendent realm after death, but one here and now resulting from liberation from impurity and egoism, is bliss: "I carry one [Moksha] about me if I would but know it" (YI April 1924). Further still, as Moksha is identified with Swaraj: "Government over self is the Truest Swaraj; it is synonymous with Moksha or salvation", (YI December 1920) and as self is viewed as a miniature nation: "self evolution is wholly consistent with a nation's evolution" (YI March 1931), Gandhian thought gets insulated from the debilitatively essentialist position, as crucial entities like God, Truth, self, nation and so on are envisaged more as processes than eternal verities.

Both Gandhi and Levinas share similar views on nation states which are considered valuable only to the extent of their ability to foster human dignity. If Gandhi bypasses nation in favour of village communities, it was due to the awareness that nations are sites, of fierce contestation, of power and of violence. "The state represents violence in a concentrated and organized form . . . the state is a soulless machine, it can never be weaned from violence to which it owes its very existence" (YI November 1928). This position does not seem to be far removed from the mainstream poststructuralist views of the nationstate such as Foucault's Panopticon, and Althusser's Repressive State Apparatus, Anderson's Imagined Communities, and so on.

If anything, it is the provisional character of Gandhi's theories, which links it to poststructuralism. For, Truth, nonviolence, God and so on in Gandhism seemingly of easy access, defy localization. He concedes that "it is difficult to know what is Truth.... and how to avoid the error in the shape of violence in one's pursuit after Truth" (YI March 1922). Even as he stressed the value of suffering, Gandhi enjoins one to "try always to avoid occasions for needless suffering" (YI March 1931). Further, he describes his programme as 'experiments' and his brand identity Satyagraha, he says, "may well prove to be the musings and doings of a fool, if not a mad man" (H September 1938). However, at the end of the day, the redeeming feature is its basis on the "Law of Love" (YI November 1919), and its being employed not "for personal gain, but for the good of others" (YI September 1926). And love, instead of clashing with the tenets of poststructuralism empowers, as Spivak would say, the subaltern: "Purnaswaraj denotes a condition of things when the dumb and lame millions will speak and walk" (YI April 1931).

Gandhi was no more fatalistic or even constructivist than any diehard poststructuralist who swears by the interplay of chance and agency. What can one call such a one who does everything possible and leaves the rest to fate? "We leave things to fate after exhausting all the remedies" (YI November 1926). And beyond that is "God", which for Gandhi" was that realm of the nontextualized sphere, the "real' which is not left unacknowledged. And Gandhi says, "God is that undefinable something which we all feel but which we do not know ... To me, God is Truth and Love, God is ethics, and morality, God is fearlessness" (YI October 1928).

Gandhi's rejection of modernism is traceable to his belief that the basis of humanity is something other than what modern science would have us believe. Gandhi approvingly quotes Huxley to insist that the "law of survival of the fittest is the law for the evolution of the brute, but the law of self-sacrifice is the law of evolution for man" (Indian Opinion July 1913). And modern civilization is doomed as it is based on the "brutal' law of the survival of the fittest, and hence is "inherently defective". Yet, in spite of the ostensible arbitrariness and oracularity of these pronouncements, they are cogent because accepting the law of survival of the fittest, is to vote against the sustainability of the universe.

Gandhi was no obscurantist. He was no more against the trappings of modernity than the evil they occasioned. His fear of our overdependence on machines and his apprehensions of possible unemployment made him suspicious of mechanization, yet he did not condemn machinery as such. He declared : "And just as, in spite of every home having its own kitchen, restaurants continue to flourish, so will mills continue to supply 
our additional wants" (YI September 1920). Regarding mechanization Gandhi was unequivocal when he declared that he "would favour the use of the most elaborate machinery if thereby India's pauperism and resulting idleness be avoided" (YI November 1921).

Gandhian ethics, rather than circumscribed by jingoist nationalism, is directed to the welfare of all. Indian political freedom, for Gandhi meant but a step "to realize and carry on the mission of the brotherhood of man" (YI April 1929), and, accordingly "if need be the whole country may die, so the human race may live . . . Let that be our nationalism" (Desai 170). Indeed the charisma of Gandhian thought is its inimitably tantalizing way of presenting radical ideas, rather innocently cloaked in traditional jargon.

\section{Levinas' Ethics And Poststructuralism}

Levinas, on the other hand, surrounded by poststructuralist ideas, does not remain completely insulated from the theoretical jargon. Yet, one is surprised by the close parallelism of these two thinkers. If the BhagvatGita energized Gandhi, Levinas acknowledged his Biblical grounding. For, as he says, "every philosophical thought rests on prephilosophical experience, and because for me, reading the Bible has belonged to these founding experiences" $(1985,24)$. Both are humanists nonpareil. The responsibility to the other is accorded primacy in both. And both, rudely jolted by the Western modernity, traverse much the same trajectory. Yet, the most obvious concursion of the two thinkers is on noninjury or ahmisa. While Gandhi viewed violence as a corollary of Western modernity, Levinas views Western philosophy itself as violent and modernity as its worst expression. He accuses Western philosophy of being a "philosophy of power . . . a philosophy of injustice" (1967, 46). For Levinas, Western philosophy is ontology, and it works by comprehending, or philosophizing the other which is violence. Ontology then is result of the refusal to recognize the radical alterity of the other. Levinas argues that such an ontology being the foundation of Western philosophy is violence. ${ }^{6}$ For, the other, being ineffable, indefinable, and radically other cannot be ontologized. Hence the violence of philosophy is a result of its attempt to know and speak about the other, which is trespass. Ontology is a violent reduction of the wholly (holy) other by representation, because the "other remains infinitely transcendent, infinitely foreign" $(1969,194)$. Violence consists in reducing the other to being which is otherwise than being, and in essentializing the other who is beyond essence. As Critchley neatly puts it, "For Levinas, Western philosophy has most often been what he calls 'ontology' by which he means the attempt to comprehend the Being of what is ..." (5).

Violence, for Levinas, consists in the other becoming the object of the study of philosophy that works by grounding itself on subject/object binary. Hence, Levinas's ethics, far from a set of precepts, is a relation prior to philosophy and ontology. And ethics, consequently, rather than a branch of philosophy, is the ground of all relation. This relation which is more than a relation is that in which one faces, speaks to and is responsible for the other. "The relationship with the other .... puts me into question, empties me of myself . . . The 'I' is expelled from this rest" (353). This renders ethics, understood as the relation to the other, prior to philosophy and the first principle. Hence, though one might describe Levinas's project as directed to the unworking of Western philosophy that functions by ontological violence, it is as much a rejection as a proffer of a viable alternative.

The repercussions of Levinas' position are many indeed. All representations, including art and literature, being ontological are in Levinasian approach, not favourably viewed. For, the other being beyond representation, the "face resists possession, resists my powers" (1969, 197). Surprisingly, Levinas spares language, which for poststructuralists failed to afford an unproblematic and innocent window to reality.

Levinas also outlines the process of unworking ontology. He says that a non-ontological relation comes to pass as language is used performatively. A performative as J.L. Austin would have it, does not seek correspondence between assertion and fact. It does not describe a state of affairs and hence the issue of verifiability does not arise. Instead, like a performative that does something more in the act of an utterance, the relation is a way of becoming exposed to the other. In other words, in a performative relation, one speaks to the other and not aboutthe other, exposed to a face at once present yet uncontainable and unencompassed.

That "thou shalt not kill" and Ahimsa, two unobtrusively harmless seeming terms, become the ground for the ethical system for both Levinas and Gandhi, is not at all undesigned. The ubiquitous use of these terms by the respective seers enables them to command greater semantic force than what two positive terms would have done for them.

Levinas's ethical system makes sense in the context of two questions he raises, viz. what is an 'I'? and how is society possible? The two questions are however better regarded as one. Levinas demonstrates why the Hobbesian answer that ' $\mathrm{I}$ ' is narcissistically striving for self-preservation and hence living in perpetual fear of all others who are guided by much the same self interest and fear of the other, is fallacious. The other in this scheme is a threat, and in consequence, everyone is an enemy of everyone else. Here, indeed is a struggle for existence. The Hobbesian ground plan views life as an ongoing struggle, all against all, in the natural state. And 
Hobbes would say that reason bids one to relinquish a part of one's privileges or striving to a political organization or a 'Leviathan', which is the key to societal life.

Obviously, the Hobbesian model of society, with self-interest at its core, leaves much to be desired, as a slight tilt can upset the applecart. Secondly, the state functioning as a repressive apparatus to ensure peace is rather intimidating. Thirdly, the weak and the poor could be justifiably ignored. In terms of sustainability, therefore, the Hobbesian model, is far from acceptable.

Hence Levinas says, it is important to know that "if society in the current sense of the term is the result of a limitation of the principle that men are the predators of one another, or if to the contrary, it results from the limitation of the principle that men are for one another" $(1985,80)$. Levinas goes on to assert that an individual is far more than Conatus Essendi, standing for and of oneself. Instead, the secret of society is the twin concepts of radical alterity and heteronomous responsibility to the other.

Indifference to the other springs from wrong assumptions according to Levinas. "Why does the other concern me? What is Hecuba to me? Am I my brother's keeper? These questions have meaning if one has already supposed that the ego is concerned only with itself, is only a concern for itself" $(1991,117)$. As for Levinas, the other is inevasible. "I cannot disentangle myself from the society with the other" $(1969,47)$, and that this relationship "precedes all ontology" $(1969,48)$, and is "prior to every memory", belonging to "a preoriginal past, anarchical past" $(1991,10)$. One's responsibility to the other marks the human in such a way so that the other becomes the soul of the self. If existence precedes essence for the Existentialist, for Levinas, heteronomous responsibility precedes even existence. This, at least, is the orientation of the huge implications, much like that of ahimsa, of "thou shall not kill". Last but not least, in terms of theoretical rigour and sustainability, Levinasian blueprint, like the Gandhian thought, should make better sense.

\section{Gandhi-Levinas Convergence}

Apart from the notion of noninjury, one can identify many points of convergence in the two thinkers. Both prefer a bottom up model on the God- question. If Gandhi identifies service to humanity with spirituality, for Levinas, 'ensoulment' by the other in one's body becomes seminal basis for divinity and goodness. As Levinas puts it: "The face of the other in proximity, which is more than representation, is an unrepresentable trace, the way of the infinite' (1991, 116). And like Gandhian lokasamgraha, universal human welfare, Levinas's face refers to all others in need, transcending segregations based on caste, class, race, nationality and so on. One is turned to "the whole of humanity, in the eyes that look at me" $(1969,213)$. And this includes the "nearby others, but also the far and absent others" $(1998,84)$, meaning people present and yet to come. This being ahimsa or 'thou shalt not kill', How can any postmodern say nay to it?

\section{Notes}

1. The ambiguous legacy of poststructuralism seems to be contradictorily coherent, in the sense that even as it fights shy of a foundation, the absence has become the basis for valorization of life in terms of gender, class, race and other interests.

2. Even as critics like Norris ["poststructuralism has removed the very possibility of reasoned, reflective and principled ethical choice"] (109) refers to the impossibility of ethics in a poststructuralist world, major theoreticians associated with the movement were trying, it seems, to demonstrate the viability of ethics. The Ethics of Psychoanalysis by Lacan, "Violence and Metaphysics", Adieu to Emmanuel Levinas and The Gift of Death by Derrida, Ethics of sexual Difference by Irigaray, Postmodern Morality by Lyotard are but a few among a host of volumes seriously exploring ethics in this context.

3. Postmodernism and Poststructuralism, riskily enough, are more or less interchangeably used in spite of some substantial differences.

4. If the Time magazine readers voted Gandhi to be second only to Albert Einstein among the most significant individuals of the $20^{\text {th }}$ century, it must be a perception that Gandhian thought held the key to many a problem plaguing humanity.

5. One feels that the world fell short of a more complete anticolonial programme than the Gandhian way. Yet it hardly found a place in the postcolonial canon.

6. Many of the poststructuralist thinkers like Derrida, Lyotard, Nietzsche and others were severely critical of philosophy, especially its totalizing character. One may not be wide of the mark in describing the entire project of Heidegger as an attempt to get behind or beyond philosophy, of which his solution being the famous Dasein. Hence Levinas was not up against a brand new struggle.

\section{Works Cited}

[1]. Critchley, Simon. The Ethics of Deconstruction: Derrida and Levinas. West Lafayette: Purdue UP. 1999.

[2]. Derrida, Jacques. Adieu to Emmanuel Levinas. Trans P. Brault and M. Naas. Stanford: Stanford UP, 1999

[3]. Desai, Mahadev, Gandhiji in Indian Villages. Madras: S. Ganesan, 1927.

[4]. Gandhi, M.K. An Autobiography or The Story of My Experiments with Truth. Ahmedabad: Navajivan, 1927. 
[5]. - Young India (1919-32) abbreviated in the text as YI.

[6]. -. Harijan $(1932-1948)$, abbreviated in the text as $\mathrm{H}$.

[7]. - The collected Works of Mahatma Gandhi. K. Swaminathan (ed). Ahamedabad: Navajivan, 1958.

[8]. Iyer, Raghavan N. The Moral and Political Thought of Mahatma Gandhi. New Delhi: Oxford UP, 1973.

[9]. Levinas, Emmanuel. Totality and Infinity. Trans. Alphonso Lingis. Pittsburgh: Duquesne UP, 1969.

[10]. - Ethics and Infinity. Conversations with Philippe Nemo. Trans. R.A. Cohen, Pittsburgh, Duquesne UP, 1985.

[11]. - Otherwise Than Being : or Beyond Essence. Trans. Alphonso Lingis. Boston: Kluwer, 1991.

[12]. - Of God Who Comes to Mind. Trans. B. Bergo, Stanford: Stanford UP, 1998.

[13]. - Adieu to Emmanuel Levinas. Trans. P. Brault and M. Naas. Stanford: Stanford UP, 1999.

[14]. Norris, Christopher. Truth and the Ethics of Criticism. Manchester: Manchester UP, 1994.

[15]. Parel, Anthony, (ed). Gandhi: Hind Swaraj and Other Writings. Cambridge: Cambridge UP, 1977.

[16]. Robbins, Jill. Altered Readings: Levinas and Literature: Chicago: Chicago UP, 1999.

[17]. Sim, Stuart. The Routledge Companion to Postmodernism. London: Routledge, 2001.

[18]. Tidrick, Kathryn. Gandhi: A Political and Spritual Life. London: I.B. Tauris, 2006. 